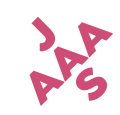

Forum: Life Writing and American Studies

10 Gillian Whitlock, "Autographics: The Seeing 'l' of the Comics," in "Graphic Narrative," ed. Hillary Chute and Marianne DeKoven, special issue, Modern Fiction Studies 52, no. 4 (2006): 965-79.

11 Sidonie Smith and Julia Watson, Reading Autobiography: A Guide for Interpreting Life Narratives (2001; Minneapolis: University of Minnesota Press, 2010), 260; Balestrini, "Hip Hop Life Writing: An Intermedial Challenge."

12 Smith and Watson, Reading Autobiography, 215.

13 Abd Al Malik, Sufi Rapper: The Spiritual Journey of Abd Al Malik, trans. Jon E. Graham (Rochester, VT: Inner Traditions, 2009).

14 Jeanette S. Jouili, "Rapping the Republic: Utopia, Critique, and Muslim Role Models in Secular France," French Politics, Culture \& Society 31, no. 2 (2013): 64.

\title{
Postcolonial and Transoceanic Life Writing
}

Katharina Fackler, University of Graz DOI: 10.47060/jaaas.v1i1.78

The study of life writing and postcolonial theory have had a long, intimate, and mutually constitutive relationship. The desire to more comprehensively understand the (human) subjectivities of the (formerly) colonized through (their own) cultural expression has driven life writing scholars to significantly expand their canon and their scholarly methods. The human and the non-human are onto-social conditions imposed on colonized and enslaved peoples. In the context of transoceanic studies, various conditions of unfreedom can be found which call attention to the prevalence of lives deemed non-human within the parameters of European Enlightenment. Substantial advances notwithstanding, the field is still grappling with what Lisa Lowe describes as the "economy of affirmation and forgetting that structures and formalizes the archives of liberalism." This short piece contends that recently emerging (trans-)oceanic approaches hold great potential for taking the study of life writing an important step further on its way beyond the liberal economy of affirmation and forgetting.

For postcolonial theorists, the type of liberal Enlightenment thinking, writing, and feeling that dominated early autobiography studies was not-or not only-emancipatory but "commensurate with, and deeply implicated in, colonialism, slavery, capitalism, and empire." 2 They claim that Western modernity can only be understood if the presumably rational, sovereign, and authentic subject of autobiography (usually Western, gendered as masculine, and racialized as white) is connected with "the less exalted or collective subject of life narrative." For this purpose, the field of life writing studies has expanded its object of study to include all "writing that takes a life, one's own or another's, as its subject." O Owing to the work of these scholars, cultural expressions such as slave narratives have now been part of the canon for decades. 


\section{is}

Nassim W. Balestrini et al.

With their help, notions of the self and of life writing have been jointly rearticulated.

Nevertheless, major challenges persist. As more recent scholarship has shown, writings by the colonized are often themselves imbricated in colonialist ways of thinking and feeling. Moreover, if life writing aims at (ego) documents that allow conclusions regarding the minds and motivations of historical actors, what about those subjects who never enjoyed historical agency within a Western(ized) public sphere? What about interdependence-oriented subjectivities, such as many members of indigenous cultures, that never had a sense of a solitary "ego" for which certain forms of life writing seemed an adequate form of cultural expression? In other words, the question still is: how can we avoid seeing life worlds merely through the eyes of those who have been privileged by what Walter Mignolo, referencing Aníbal Quijano, calls the "colonial matrix of power"?5

Many recent impulses on how precisely humans and their life narratives can be understood more comprehensively come from spaces formerly considered marginal to cosmopolitan knowledge production, such as "the ex-slave archipelago."6 Jamaican writer and cultural theorist Sylvia Wynter's work, for example, powerfully challenges critics to move beyond a "monohumanist" conception that constitutes the bourgeois, complete, Western Man as the human and that denies full humanity to others. As a substitute for the Western biocentric model, she proposes an understanding of humans as "hybrid being[s]" who are defined by the biological ("bios") and by their narratives ("mythoi") at the same time. " Consequently, humanness is no longer understood as a (stable, centered) noun, but as a "praxis" that enables different "genres of being human." "Wynter makes a persuasive case for "the central role that our discursive formations, aesthetic fields, and systems of knowledge must play in the performative enactment of all such genres of being hybridly human."9 Transferred to literary studies, Wynter's theory demands a radical expansion of our understanding of life narratives and their subjects.

Given the centrality of ocean-crossings not only for the Black but also for the Native American and the Asian American experience, it may hardly surprise that many responses to such challenges are inspired by transoceanic human im/mobilities. Such perspectives, I argue, have a particular potential for un-settling the epistemologies of (settler) colonialism. Recent work on oceanic writing is interested in all kinds of marine experiences, not only those of explorers and voluntary migrants but also those of the enslaved, the indentured, and the conscripted in both the Atlantic and the Pacific worlds. This includes the countless individuals who never made it across the ocean or never lived to see emancipation, to learn how to read and write, or to attain a voice in a culture that deprived them of their humanity. The histories of these ocean-crossings, which often played out on ships, islands, or archipelagoes, 


\section{3}

Forum: Life Writing and American Studies

are now considered defining elements of the experience of modernity and an indispensable complement to Enlightenment narratives of free individuals and universal progress. $^{10}$

The material properties of the ocean, its ever-moving fluidity, and its underwater worlds provide rich conceptual resources for rethinking life narratives. For instance, the ocean can serve "as a methodological model for nonlinear or nonplanar thought." "I Kamau Brathwaite's notion of "tidalectic, "12 which is inspired by the ebb and flow of the sea, offers an alternative cyclical model of history: Distinct from the linear teleology of Enlightenment thinking and autobiography, it opens up alternative temporalities and geographies, and thus invites resistant reading practices. ${ }^{13}$ These reading practices also ask us to more thoroughly entangle the economic and the ecological. ${ }^{14}$ Besides, oceanic fluidity draws our attention away from the "supposedly enduring materials (i.e., texts, documents, buildings, bones)" of the archive and towards what Diana Taylor calls the "repertoire of embodied practice/knowledge (i.e., spoken language, dance, sports, ritual)" that frequently constitutes the expression of the colonized..$^{15}$ As the stories of the drowned often remain submerged within the ocean without perceptible traces, they challenge scholars to find new ways to approach archival silence. Oceanic connections also invite us to critically question traditional notions of area, nation, and race. This implies, among other things, putting Atlantic and Pacific, ${ }^{16}$ white, black, Asian, and indigenous perspectives into conversation with one another. It means, for instance, studying the African diaspora alongside Native American experiences of settler colonialism and alongside South and East Asian diasporas. By way of examples, I would like to point out three different strategies by which pioneering life writing scholars put these theoretical concerns into practice. These strategies include resistant readings of more established sources, the opening up of new digital archives, and attentive approaches to archival silence.

As Lisa Lowe reads the Interesting Narrative of the Life of Olaudah Equiano (1789) against the liberal-teleological grain, she demonstrates how an innovative angle can tease out new perspectives from an established life writing genre. British abolitionists interpreted this oceanic life narrative, in which the enslaved African subject seems to rise to liberal personhood, as affirmative of the possibilities of individual emancipation, Christian redemption, and liberal economy. Lowe, by contrast, traces the residues of slavery, of the "unremediated collective condition of inhuman cruelty and survival," that defy the hopeful tale of progress. For instance, Equiano's narrative breaks the temporality of emancipation by referencing and echoing Ottobah Cugoano's Thoughts and Sentiments on the Evil and Wicked Traffic of the Slavery and Commerce of the Human Species (1787). The latter narrative affirms that "the bitterness of grief and woe" remains with him despite his manumission. "Slaves, exslaves, and others," Lowe argues, "could 'listen' to the complex tones of 


\section{0}

Nassim W. Balestrini et al.

Equiano's narrative, and hear the 'otherness' embedded within the text."17 Moreover, she exposes how British abolitionism offered an ideological basis for British imperial expansion in Sierra Leone, which she proves to be connected with settlers' wars with native peoples. She then shows how the framework of liberal freedom fostered the transition from slavery to "free" Chinese and Indian labor "recruited" to British, French, and Spanish colonies under indenture. Lowe's transoceanic reading practice disrupts the liberal monohumanist universalism and places it within the critical space of what she characterizes as the transoceanic intimacies of four continents.

When it comes to more recent oceanic migrations, new digital and mobile technologies offer sources for new kinds of narratives. Alfred Hornung's coinage "outof-life narratives" denotes stories whose migrating subjects are not just "in and out of language, being in and out of worlds," but also "in and out of life," as their humanity is put into question through violent policies. Among others, he includes the texts, images, and data on refugees' smartphones into the category of out-of-life narratives. These life narratives are hardly characterized by unified teleologies. Rather, he argues, they "consist of the random arrangement of exclusively short episodes of exterritorial existence."18

Jenny Sharpe, in turn, develops a method of listening to the silence of the archives in her reading of Marlene Nourbese Philip's Zong! (2008). This book of poems is based on a legal case that presents the only preserved record of a 1781 incident in which 142 enslaved Africans were thrown overboard and killed so that the slave boat's owners could reap insurance benefits. Framed as a question of insurance fraud, the case in no way acknowledged the humanity of those who drowned. As the ocean swallowed their voices, it is within the gaps of the archives-which Zong! reconstructs as graphic gaps on the page-that Sharpe sees "spaces of affect" and "visceral sensations" rather than visual images. ${ }^{19}$ She argues that this kind of scholarly work focuses less on offering historical facts than on careful attentiveness to archival silence: "What I am calling an affective relationship to the archive does not involve unearthing new historical data so much as understanding silence as a haunting limit of what was recorded."2o

Filling the gaps in the post/colonial auto/biographical archives and uncovering "new stories of being human" requires substantial creative efforts both on the part of life writers and of life writing scholars. ${ }^{21}$ In this way, the fundamental tension between the desire to include all lives in research and teaching and the fact that some subjectivities can barely be perceived outside their own existence may persist. Yet life writing scholars' awareness of the field's limitations and their ingenuity and creativity in seeking to overcome them may well remain a defining feature of the field. 


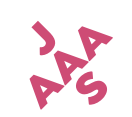

Forum: Life Writing and American Studies

\section{Notes}

1 Lisa Lowe, The Intimacies of Four Continents (Durham, NC: Duke University Press, 2015), 3 .

2 Ibid., 2.

3 Gillian Whitlock, Postcolonial Life Narratives: Testimonial Transactions (New York: Oxford University Press, 2015), 3.

4 Sidonie Smith and Julia Watson, Reading Autobiography: A Guide for Interpreting Life Narratives (2001; Minneapolis: University of Minnesota Press, 2010), 4.

5 Walter Mignolo, "Introduction: Coloniality of Power and De-Colonial Thinking," in "Globalization and the De-Colonial Option," ed. Walter Mignolo, special issue, Cultural Studies 21, nos. 2-3 (2007): 156, https://doi.org/10.1080/09502380601162498.

6 Katherine McKittrick, "Yours in the Intellectual Struggle: Sylvia Wynter and the Realization of the Living," in Sylvia Wynter: On Being Human as Praxis, ed. Katherine McKittrick (Durham, NC: Duke University Press, 2015), 2.

7 Sylvia Wynter and Katherine McKittrick, "Unparalleled Catastrophe for Our Species? Or, to Give Humanness a Different Future: Conversations," in Sylvia Wynter: On Being Human as Praxis, ed. Katherine McKittrick (Durham, NC: Duke University Press, 2015), $14-6$.

8 Ibid., 31.

9 Ibid.

10 Paul Gilroy, The Black Atlantic: Modernity and Double Consciousness (1993; London: Verso Books, 2002).

11 Hester Blum, "Introduction: Oceanic Studies," in "Oceanic Studies," ed. Hester Blum, special issue, Atlantic Studies: Global Currents 10, no. 2 (2013): 151, https://doi.org/10.108 o/14788810.2013.785186.

12 Kamau Brathwaite, ConVERSations with Nathaniel Mackey (Rhinebeck, NY: We Press, 1999), 34 .

13 Elizabeth M. DeLoughrey, Routes and Roots: Navigating Caribbean and Pacific Island Literature (Honolulu: University of Hawai'i Press, 2007), 1-48; Anna Reckin, "Tidalectic Lectures: Kamau Brathwaite's Prose/Poetry as Sound-Space," Anthurium: A Caribbean Studies Journal 1, no. 1 (2003), https://doi.org/10.33596/anth.4.

14 Michelle Burnham, "Oceanic Turns and American Literary History in Global Context," in Turns of Event: Nineteenth-Century American Literary Studies in Motion, ed. Hester Blum (Philadelphia: University of Pennsylvania Press, 2016), 151-71.

15 Diana Taylor, The Archive and the Repertoire: Performing Cultural Memory in the Americas (Durham, NC: Duke University Press, 2003), 19.

16 Juliane Braun, “Strange Beasts of the Sea': Captain Cook, the Sea Otter and the Creation of a Transoceanic American Empire," in "Across Currents: Connections between Atlantic and (Trans)Pacific Studies," ed. Nicole Poppenhagen and Jens Temmen, special issue, Atlantic Studies: Global Currents 15, no. 2 (2018): 238-55, https://doi.org/10.108 o/14788810.2017.1387462; Burnham, "Oceanic Turns"; DeLoughrey, Routes and Roots; Alexandra Ganser, "From the Black Atlantic to the Bleak Pacific: Re-Reading 'Benito Cereno," in "Across Currents: Connections between Atlantic and (Trans)Pacific Stud- 


\section{0}

Nassim W. Balestrini et al.

ies," ed. Nicole Poppenhagen and Jens Temmen, special issue, Atlantic Studies: Global Currents 15, no. 2 (2018): 218-37, https://doi.org/10.1080/14788810.2017.1384612; Nicole Popphenhagen and Jens Temmen, "Across Currents: Connections between Atlantic and (Trans)Pacific Studies," in "Across Currents: Connections between Atlantic and (Trans)Pacific Studies," ed. Nicole Poppenhagen and Jens Temmen, special issue, Atlantic Studies: Global Currents 15, no. 2 (2018): 149-59, https://doi.org/10.1080/14788810. 2017.1394131. Also see the May 2018 conference on "Transoceanic American Studies" organized by Juliane Braun and Benjamin Fagan at the German Historical Institute in Washington, DC.

17 Lowe, Four Continents, 58.

18 Alfred Hornung, "Out of Life: Routes, Refuge, Rescue," in “Excavating Lives," ed. Amy-Katerini Prodromou and Nicoletta Demetriou, special issue, a/b: Auto/Biography Studies 32, no. 3 (2017): 6o5, https://doi.org/10.1080/08989575.2017.1339999.

19 Jenny Sharpe, "The Archive and Affective Memory in M. Nourbese Philip's Zong!" Interventions 16, no. 4(2014):475, https://doi.org/10.1080/1369801X.2013.816079.

20 Ibid., 480.

21 McKittrick, "Yours in the Intellectual Struggle," 7.

\section{Outlook on Life Writing and American Studies}

Silvia Schultermandl, University of Graz, and Nassim W. Balestrini, University of Graz DOI: 10.47060/jaaas.vii.106

Having discussed five distinct areas of inquiry within life writing studies, we are acutely aware of the various interconnected themes. By way of a conclusion, we would like to sketch three particular aspects which merit extensive attention. First, the fact that all of the contributions highlight the constructedness of life writing can be seen as a call for enhancing our understanding of the mechanisms of self-representation and their implications for the represented autobiographical self and for the multi-genre phenomenon of life writing. The field of life writing studies has been instrumental in uncovering multiple phenotypes linked to medium-specific possibilities and to the contexts in which such content is generated, disseminated, and received. Thus, we will need to grapple further with researching competing and differing media selves, including the roles of curators and adapting generic forms like the scrapbook and the self-help manual as well as the economic backdrop and impact of production and distribution.

Second, our contributions illustrate the ongoing discussion about the mediality of autobiographical self-representation. What are the upsides and downsides of broadening the terms "text" and "discourse" to non-verbal media in life writing studies? Does it suffice to regard such self-depictions as "life narratives," or does this water down the particular capacities of verbal semantics? As our contempla- 